perifèria

Número 21(1), junio 2016

http://revistes.uab.cat/periferia

\title{
Desabrochando uma rosa de um rocket: memoria, performance e resistência na arte moçambicana
}

\author{
Sílvia Raposo - Faculdade de Ciências Sociais e Humanas, Universidade \\ Nova de Lisboa - Centro em Rede de Investigação em Antropologia ${ }^{1}$ \\ http://dx.doi.org/10.5565/rev/periferia.505
}

\section{Resumen}

Este artigo procura compreender, através do trabalho artístico de Gonçalo Mabunda, como o Núcleo de Arte de Maputo leva a cabo uma «reciclagem» e reprodução dos ícones de guerra, de forma a criar toda uma produção identitária baseada na memória histórica. Debruço-me sobre a forma como as esculturas podem abrir espaço a um lugar de memória liminar que permite a negociação de significados e mnemónicas associadas à Guerra Civil, espelhando contra-memórias coadas pela experiência pessoal do artista. Analisa-se a capacidade expressiva e simbólica da linguagem escultórico-performativa enquanto comunicadora de significados sociais e políticos, e como forma de mise-èn-scene do «drama social».

Palabras clave: Escultura; performance; resistência; memória.

\begin{abstract}
This article seeks to understand, through the artwork of Gonçalo Mabunda, as the Maputo Art Center carries out a 'recycling' and reproduction of war icons in order to create an entire identity production based on historical memory. I lean over on how sculptures can make room to a place of memory injunction allowing the negotiation of meanings and mnemonics associated with the Civil War, mirroring countermemories strained by the artist's personal experience. It analyzes the expressive and symbolic capacity of sculptural-performative language as communicator of social and political meanings, and as a form of mise-èn-scene of "social drama".
\end{abstract}

Keywords: Sculpture; performance; resistance; memory.

\section{Introdução:}

O emblema da República de Moçambique tem desenhado no centro um rifle Kalashnikov AK-471, simbolizando a luta contra o regime colonial que culminaría na

\footnotetext{
${ }^{1}$ Enviar correspondencia a: Sílvia Raposo silvia961993@gmail.com
} 


\section{perifèria}

Número 21(1), junio 2016

http://revistes.uab.cat/periferia

independência do país em 1975. É certo que as décadas de 1970 e 1980 foram marcadas por diversos conflitos armados, sendo que entre 1977 e 1992 Moçambique seria atravessado por uma violenta Guerra Civil (Cruz e Silva, 2001).

A situação histórica e geográfica de Moçambique, em grande parte devido aos conflitos armados que atravessaram o país, é marcada por inúmeros processos migratórios, originando um mosaico cultural, uma vez que a população moçambicana, oriunda de povos dispersos da etnia Banto (e estimada entre 15.7 milhões de habitantes) apresenta características multiétnicas, para as quais a influencia da colonização portuguesa contribuiu fortemente (Idem).

Posto isto, no séc. XX assiste-se a um aumento significativo de grupos nacionalistas, sendo que o processo de independência de Moçambique foi encabeçado pela Frente de Libertação de Moçambique (FRELIMO) que, em 1962, reúne grupos nacionalistas a favor do fim da exploração colonial. O país conquista a sua independência após o fim do regime ditatorial português com a Revolução dos Cravos, em 1974 (Ribeiro, 2014). Contudo, a bipolarização ideológica que decorreu da Guerra Fria conduziu a posicionamentos por parte dos governos africanos que se encontravam em processo de descolonização, sendo que a FRELIMO, por ter incorporado um sistema político de cariz colectivista, típico dos países socialistas do Leste Europeu, manteve-se isolada dos restantes processos de independência. Isto resultou em que as práticas governamentais adoptadas pela FRELIMO causassem inconvenientes aos restantes governos africanos, sendo que a situação se agrava quando a FRELIMO concede apoio e asilo político a guerrilheiros pró-Zimbabue na Rodésia do Sul, o que origina uma retaliação por parte do país vizinho que reúne ex-soldados moçambicanos que manifestavam uma ideologia política contrária à da FRELIMO e formam a Resistência Nacional de Moçambique (RENAMO). As investidas da RENAMO levam a uma longa Guerra Civil que apenas culmina em 1992 (Idem).

Durante a Guerra Civil, Moçambique vê destruída uma grande parte das suas infraestruturas económicas e sociais. Mas, apesar do conflito ter afectado o comercio rural, a população permanece predominanatemente rural e a economía do país continua a assentar marioritariamente na agricultura ( $80 \%$ do sector económico), atendendo a que a industria manufactureira, desenvolvida durante o sistema colonial, apresentava uma base frágil que, também com a Guerra Civil, 


\section{perifèria}

Número 21(1), junio 2016

http://revistes.uab.cat/periferia

acaba por entrar em crise (Cruz e Silva, 2001). Já em 1992 a RENAMO e a FRELIMO iniciam as conversações tendo em vista o cessar fogo e o Acordo Geral de Paz. Assim, em 1994, decorriam as primeiras eleições presidenciais em Moçambique, sendo que o processo de transição política vê-se, então, consolidado nos anos 90. Contudo as sucessivas crises económicas e os processos de transição que decorreram ao longo deste processo resultaram numa incapacidade estatal para reduzir os efeitos sociais negativos das reformas económicas, traduzindo-se num aumento dos níveis de pobreza, exclusão social e violência (Idem). É portanto, a este nível que surge o projecto artístico do TAE (Transformação de Armas em Enxadas), sobraçado pelo Conselho Cristão de Moçambique no ámbito de uma consciencialização em torno da Guerra Civil e das políticas de desarmamento levadas a cabo pelo governo e sociedade civil.

Posto isto, este artigo tem como objectivo, através de uma evidência da arte enquanto lugar de memória, demonstrar de que modo o TAE, coloca a cultura em cena através da escultura e como, partindo da memória social e traumática da Guerra Civil Moçambicana, leva a cabo uma «reciclagem» e reprodução dos ícones de guerra, de forma a criar uma produção identitária baseada na memória histórica, através da qual se pretende apelar às ligações entre arte e política, potenciando a arte enquanto acto de resistência e subversão. Para tal este artigo baseia-se nas obras de um dos artistas que integra o TAE - Gonçalo Mabunda através das quais procurarei compreender como a partir da escultóricoperformatividade se abre um espaço de negociação de significados e mnemónicas associadas aos objectos da Guerra Civil, fazendo emergir contra-memórias coadas pela experiência traumática dos artistas que procuram provocar o dissenso tendo em vista a resistência e agencia social.

Pretende-se assim analisar de que modo se reinventa a tradição artística através da capacidade expressiva e simbólica da linguagem escultórico-performativa enquanto comunicadora de significados sociais, refletindo a mundividência do sujeito-artífice, visando assim incrementar um debate crítico em torno dos campos político e social. Isto faz com que parte da minha análise recaia, roubando a metáfora inicial a Artaud, sobre o caracter pestífero das artes, ou seja, "através da peste, e coletivamente, um gigantesco abscesso, tanto moral quanto social, é vazado" 


\section{perifèria}

Número 21(1), junio 2016

http://revistes.uab.cat/periferia

(Artaud, 1983: 28), pelo que a proposta é precisamente reforçar a ideia de que a arte serve para vazar abscessos coletivamente.

No que diz respeito à metodologia utilizada neste estudo, decidi optar por uma metodologia qualitativa, nomeadamente entrevista etnográfica e fontes documentais. Quanto ao carácter do "speech event" dei privilégio à entrevista estruturada, bem como às descriptive questions (Spradley, 1979: 466), tendo recorrido a uma amostragem intencional (Burgess, 1997). Para tal, reuni testemunhos de vários artistas do Núcleo de Arte de Maputo, embora para a análise que este artigo propõe fazer tenha selecionado o artista Gonçalo Mabunda como meu informante-chave. O motivo desta seleção adveio da exposição Ocupações Temporárias - Documentos, da Fundação Calouste Gulbenkian, em Lisboa, na qual o artista Gonçalo Mabunda expôs algumas das suas obras em 2013 e do qual obtive conhecimento através de uma colega antropóloga que na altura esteve envolvida na organização do evento. Assim, quando me propus a fazer esta análise ponderei ter como foco a obra de Gonçalo, atendendo ao carácter explicitamente artivista do discurso e das obras do artista que considero representativos da relação entre arte e política, nomeadamente da forma como a arte pode acompanhar um projecto politico e de como os objectos artísticos podem apresentar um conteúdo politico e critico que é imeditamente reconhecido, para tal recorrendo à memória histórica e social, uma vez que na arte irrompem as tensões e conflitos do sistema social (Oliveira, 2011).

É, sobretudo, através do poder simbólico da imagem, no sentido em que esta participa num processo de comunicação que engloba uma mensagem, protagonistas, código, canal e contexto, que a arte, ao preencher uma expressão performativa (Saouter, 2005), comunica um sistema de valores, crenças e sentimentos, cuja interpretação pode impelir o questionamento da organização política ou o apoio e contestação em relação a este (Oliveira, 2011). Na verdade, a maior potencialidade da arte reside na sua capacidade de problematizar e antecipar transformações sociais. Posto isto, termino esta introdução manifestando as questões de partida que servirão a minha análise: de que modo a memória pode ser articulada com a prática artística e servir de instrumento político? Poderá a escultura mobilizar recursos e repertórios próprios do campo da política? Existirá 


\section{perifèria}

Número 21(1), junio 2016

http://revistes.uab.cat/periferia

uma relação entre arte e activismo? Poder-se-á falar em resistência e/ou objectificação $e$, atendendo às iniciativas comerciais no universo da arte, mercantilização da resistência?

\section{Viagem a um país estrangeiro, passando por Moçambique...}

Para os mortos, o tempo está pisando as pegadas da véspera. Para eles nunca há surpresa. (Couto, 1996: 7)

O campo da antropologia da performance é possível de ser entendido, nas palavras de Geertz, como "um manuscrito estranho e desbotado, cheio de elipses, incoerências, emendas suspeitas e comentários tendenciosos" (Geertz apud Dawsey, 2007: 531), constituindo-se como uma «anti-disciplina», ele próprio uma espécie de campo liminar. Mas, de acordo com Victor Turner, "os lugares onde um texto se desmancha podem ser os mais fecundos" (Dawsey, 2007: 531), pelo que rapidamente o antropólogo britânico se aventurou numa cruzada por entre as sinuosas veredas dos rituais e dos dramas sociais nos anos 50, com trabalho de campo entre os Ndembo. Turner, ao lado de Schechner lançavam as sementes que criariam raízes por volta das décadas de 70 e 80 , quando se avizinharia o novo campo disciplinar. $\mathrm{E}$ ao passo que germinariam os frutos deste campo de estudos, 0 interesse pela performance abalroava as fronteiras da disciplina, evocando-se uma distinção entre teatro e metateatro: enquanto o sociólogo Erving Goffman (1959) autopsiava a performance quotidiana, Turner focava-se nos momentos de excepção, sobraçando o metateatro da vida social (Dawsey, 2007).

Explorando as relações entre ritual e teatro, Turner apercebeu-se que o ritual estaria encrustado ao processo social e que esse seria também performativo (Schechner, 1986). As suas conviç̧ões quanto ao carácter dinâmico das relações sociais, fizeram-no notar uma forma no processo do tempo social que era essencialmente dramática. Turner elabora, deste modo, um modelo de Drama Social baseando-se no arquétipo dos ritos de passagem de Van Gennep (Turner, 2008), como veremos mais adiante. 


\section{perifèria}

Número 21(1), junio 2016

http://revistes.uab.cat/periferia

Refere o autor que uma das característica mais marcantes na vida social dos Ndembo era a propensão ao conflito, conflito que se manifestava "em episódios de irrupção pública de tensão" (Turner, 2008: 28), ou seja, «dramas sociais». Explicitando melhor o termo, para Tuner os dramas são

Literary compositions that tell a story, usually of human conflict, by means of dialogue and action, and are performed by actors and presented to an audience, the nature and degree of whose involvement and participation varies from culture to culture" (Turner, 1986: 27).

Assim, procurou formular uma «forma processual do drama», reforçando que os dramas sociais podem ser isolados para investigação em qualquer sociedade, independentemente da sua dimensão e complexidade (Turner, 2008). Acrescenta ainda que no «drama social» o ênfase recai sobre a lealdade e obrigação, possibilitando que o curso dos acontecimentos possam adquirir uma qualidade trágica (Tuner, 2008)

De acordo com o pensamento de Turner, eventos menos dramáticos preparam gradualmente o terreno para confrontos de maior dimensão, sendo que "os distúrbios do normal e do regular muitas vezes nos oferecem um maior insight sobre o normal do que o estudo directo" (Tuner, 2008: 30), fazendo com que a estrutura se revele através da anti-estrutura ou contra-estrutura. De acordo com o autor, o conflito permite que os aspectos essenciais da sociedade, encobertos pelo costume e hábito, ganhem proporções assustadoras, para além de obrigar os sujeitos a tomar posições. Assim, os «dramas sociais» apresentam-se como "unidades de processo anarmónico ou desarmônico que surgem em situações de conflito" (Turner, 2008: 33).

Estes tais «dramas sociais» geralmente representam sequências de eventos sociais que têm uma estrutura tecida de acordo com os fios do tempo, mas "a estrutura de fases do drama social não é produto do instinto, e sim de modelos e metáforas que os atores carregam nas suas cabeças" (Turner, 2008: 31). Mas é certo que, como destaca Calvanti, "a ideia orgânica e propriamente dramatúrgica do drama social (...), no qual uma fase gesta a outra desde dentro, as ações respondendo-se umas às outras e desdobrando-se em novas ações, trouxe certamente a temporalidade 


\section{perifèria}

Número 21(1), junio 2016

http://revistes.uab.cat/periferia

processual como uma dimensão central para a apreensão do dinamismo da vida social (Calvanti, 2013: 418).

Explicitando a afirmação da autora, Turner, baseando-se nas fases dos ritos de passagem do Van Gennep, ou seja, separação, margem e agregação, apresentanos um quadro faseado do «drama social», sendo a sua proposta marcada por "uma autonomização da fase liminar" (Godinho, 2014B: 12). Argumenta o autor que todas as crises públicas apresentam características liminares, fazendo referência a um liminar entre fases relativamente estáveis do processo social, como iremos verificar no caso moçambicano.

Por semelhança a outras colónias portuguesas, a independência de Moçambique foi conquistada através de uma luta armada, encabeçada pela Frente de Libertação de Moçambique (FRELIMO). A FRELIMO resultou da unificação de movimentos nacionalistas visando a luta contra o colonialismo e tendo uma ideologia de inspiração Marxista que defendia a criação de uma sociedade sem classes. Após a independência em 1975, até por volta da década de 80, a FRELIMO, adaptou uma politica económica Marxista e constituiu-se enquanto partido político, impondo um sistema de partido único. A dissidência resultante do impacto destas medidas nas estruturas sociais tradicionais barricou a emergência da unidade nacional, gerando as fontes de recrutamento que as potências hostis regionais careciam para boicotar o processo de edificação nacional. É deste modo que, apoiada pelos regimes hostis, emerge a Resistência Nacional de Moçambique (RENAMO) (Leão, 2004). Temos, portanto, aqui o primeiro momento do «drama social», ou seja, o reconhecimento de uma crise, manifestando tensões e posterior ruptura das relações sociais formais (Turner, 2008).

Entretanto, a RENAMO levou a cabo diversas incursões armadas, levando à decadência da vida rural e a uma terrível Guerra Civil durante 14 anos, justificada essencialmente por questões étnicas (Leão, 2004). Emergindo aqui o segundo momento do «drama social», após irromperem as tensões latentes à relações e interações sociais. Portanto, dá-se uma ampliação da crise, envolvendo cada vez mais actores, pautando-se por um momento de inflexão, perigo e suspense que permitiu revelar um verdadeiro estado de coisas (Turner, 2008). 


\section{perifèria}

Número 21(1), junio 2016

http://revistes.uab.cat/periferia

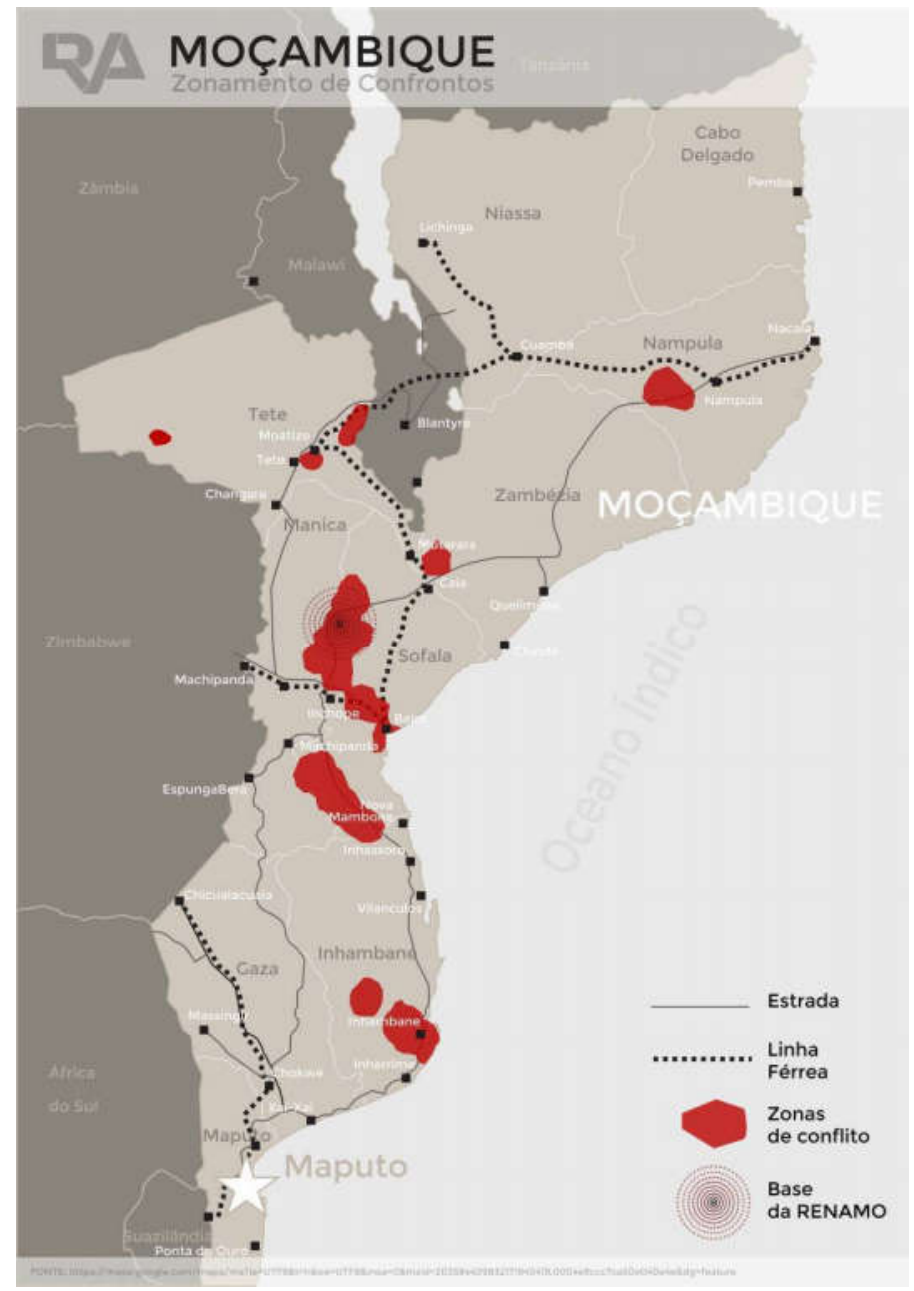

Fig. 1 - Principais zonas de conflito entre a RENAMO e a FRELIMO até à actualidade $^{2}$.

A terceira fase deste «drama social» moçambicano trata-se da acção correctiva. Nesta fase as técnicas pragmáticas, bem como a acção simbólica são expressadas em pleno, pois "aqui, a sociedade, grupos, comunidade (...), está em seu momento mais "auto-consciente" e pode atingir a clareza de pensamento de uma pessoa encurralada, lutando pela vida" (Turner, 2008: 36). A própria fase correctiva ou

2 Fonte: Rede Angola. (2014) «Há guerra em Moçambique». Disponível em < http://www.redeangola.info/especiais/ha-guerra-em-mocambique/> [consultado a 18 de Maio de 2016]. 


\section{perifèria}

Número 21(1), junio 2016

http://revistes.uab.cat/periferia

regenerativa possui traços liminares, fornecendo "uma réplica e uma crítica distanciada dos eventos que compuseram e levaram à crise" (Turner, 2008: 36). É portanto nesta fase que enquadro o processo de instauração de paz. Processo este que teve inicio com o culminar da guerra civil em Moçambique e a assinatura de um Acordo Geral de Paz em 1992, seguindo-se um longo processo de instauração de paz encabeçado pelas Nações Unidas com o apoio da Operação das Nações Unidas em Moçambique, até finais de 1994. Aplacadas as fúrias bélicas que submeteram o país a vários conflitos armados - a luta pela independência entre 1964 e 1974 e os 14 anos que se seguiram da guerra civil -, Moçambique emerge finalmente por entre os escombros da Guerra.

Finalmente, a última fase do «drama social», ou seja, o rearranjo ou cisão, manifesta-se após a retirada da operação da Nações Unidas, em 1995. É nesta fase que, pautada pela reintegração do grupo social perturbado ou reconhecimento e legitimação social do cisma irreparável entre as partes do conflito, é permitido fazer o balanço da situação, enquadrando-se aqui uma consciencialização em torno da Guerra Civil e as políticas de desarmamento levadas a cabo pelo governo e sociedade civil. Explicitando melhor, o país viu-se a braços com uma enorme proliferação de armas ligeiras e de pequeno porte. Face a isto, os governos de Moçambique e África do Sul implantaram a «operação Rachel», uma iniciativa de desarmamento que vem sendo desenvolvida paralelamente a outras iniciativas levadas a cabo pela sociedade civil. É portanto, enquadrado nesta última fase do drama social e nos esforços civis que emerge o projecto TAE - Transformação de Armas em Enxadas -, sobraçado pelo Conselho Cristão de Moçambique (2004).

O projecto consistia essencialmente em trocar armas na posse de indivíduos privados por chapas de zinco, bicicletas, máquinas de costura, tractores, enxadas, arados, portas, janelas, ou utensílios de cozinha, visando assim "estabelecer uma cultura de paz num país devastado pela guerra e desastres naturais" (Faltas e Paes, 2004: 19). No entanto, rapidamente se verificou que as armas recebidas para troca advinham de esconderijos e não de indivíduos privados, o que na altura suscitou vários questionamentos por parte dos implementadores do projecto, isto no que diz respeito às informações obtidas sobre os esconderijos de armas. Esta e outras 


\section{perifèria}

Número 21(1), junio 2016

http://revistes.uab.cat/periferia

situações levaram a que o projecto TAE deixasse de ser autonomizado para passar a integrar a «Operação Rachel» (Leão, 2004).

Entretanto, o projecto TAE decidiu, para além da colecta, troca e destruição de armas, transformar em peças de arte as armas destruídas, apresentando-as ao público. Para tal, levou a cabo um projecto, em colaboração com o Núcleo de Arte de Maputo, que visava a transmutação das armas em objectos artísticos, transformando os fragmentos de armas em símbolos de paz (Faltas e Paes, 2004: 19). (Faltas e Paes, 2004). A minha proposta é, portanto, analisar estes objectos artísticos produzidos pelo TAE como uma forma de mise-en-scène do drama social da Guerra Civil Moçambicana, evocando a memória histórica e a forma como esta é reinventada e manipulada pelas classes subalternas em seu próprio proveito. Ainda, coloco em cena a invenção das tradições através da transformação das armas em obras de arte que estabelecem uma relação mais ou menos artificial com o passado histórico e contexto de produção de origem, pois "toda a tradição inventada, na medida do possível, utiliza a história como legitimadora das ações e como cimento da coesão social" (Hobsbawn, 1984: 21).

\section{Viajante no país de Lowenthal...}

Só quem viveu na pele a guerra e a paz é capaz de fazer desabrochar uma rosa de um rocket. (Rolletta, 2008: 17)

A minha predileção por metáforas leva-me a saltar para as questões da memória através de uma obra bastante controversa na época, intitulada $O$ teatro e o seu duplo (1983), de Antonin Artaud. A imagem espiritual da peste, evocada por Artaud nesta obra reforçava que os humores perturbados do pestífero seriam "a face solidificada e material de um distúrbio que, em outros planos, equivale aos conflitos, às lutas, aos cataclismos e débacles que os acontecimentos nos trazem" (Artaud, 1983: 21). Assim, os conflitos políticos, a ordem da revolução e a desordem da guerra, em suma, o «drama social» ao se reflectir no plano da performance que, neste caso, se manifesta através da escultura, descarrega-se "na sensibilidade de quem o observa com a força de uma epidemia" (Artaud, 1983: 


\section{perifèria}

Número 21(1), junio 2016

http://revistes.uab.cat/periferia

22). Mas é certo que esta epidemia, esta mise-èn-scene do «drama social» é tecida no momento em que encruzilham as teias da memória com as tramas do esquecimento. Urdida no palco da história, a mise-èn-scene do «drama social» compõe-se a partir de memórias e esquecimentos.

Salientava David Lowenthal que o passado "é um país estrangeiro cujos atributos são configurados pelos gostos de hoje, e as suas peculiaridades são domesticadas pela nossa própria preservação dos seus vestígios" (Lowenthal apud Godinho, 2012: 13). Assim, parafraseando Godinho, este artefacto do presente é construído, negociado, contrafeito e cobiçado, sendo um passado autenticado que se torna um modelo do presente "forjado a partir de ferramentas modernas" (Godinho, 2012: 13). O que permite reviver continuamente a nossa consciência daquilo que foi $o$ passado são a memória, história e fragmentos (Lowenthal, 1995). No entanto, a memória não é menos residual do que a história, pois, por mais nítidas e abrangentes que sejam as recordações, não passam de "meros lampejos do que já foi um todo vivo" (Lowenthal, 1995: 74). Como reforça Lowenthal, parafraseando Simone de Beauvoir; "nós o vivemos no presente; ... e tudo o que resta é um esqueleto" (Lowenthal, 1995: 74), pois o passado rapidamente se encontra envolto por sombras, priva-se de sensações, sendo apagado pelo esquecimento (Lowenthal, 1995).

É certo que a nossa consciência do passado se funda na memória, e é através das lembranças que recuperamos a consciência dos acontecimentos passados (Lowenthal, 1995), sendo que a lembrança é "uma imagem engajada em outras imagens, uma imagem genérica reportada ao passado" (Halbwachs, 1990 [1950]: 73). Estas lembranças são, de acordo com Halbwachs, «reconstruidas» ou «simuladas». Reconstruídas por serem "uma reconstrução do passado com a ajuda de dados emprestados do presente" (Halbwachs, 1990 [1950]: 71), sendo preparadas por outras reconstruções efectuadas em épocas anteriores nas quais a imagem de outrora já se manifestava alterada (Halbwachs, 1990 [1950]). E simuladas porque, à medida que a lembrança vai recuando no passado vai-se transformando, umas impressões apagam-se, outras evidenciam-se, de acordo com "o ponto a partir do qual a encaramos, isto é, segundo as condições novas onde ela se encontra quando nos voltamos para ela" (Halbwachs, 1990 [1950]: 74). Todas 


\section{perifèria}

Número 21(1), junio 2016

http://revistes.uab.cat/periferia

as impressões, os novos julgamentos e reflexões, os detalhes e circunstâncias narrados por outrem sobre determinado acontecimento ou pessoa são como manchas desferidas na paleta das lembranças, prontas a retocar o retrato dos acontecimentos:

À semelhança de acervo de antiguidades, nosso repertório de lembranças preciosas está em fluxo contínuo, novas lembranças sendo adicionadas constantemente, as velhas sendo descartadas, umas emergindo à superfície da consciência presente, outras submergindo sob a atenção consciente. (Lowenthal, 1995: 78)

É deste modo que "o passado (...) se enfraquece lentamente" (Halbwachs, 1990 [1950]: 74).

\section{Núcleo de Arte de Maputo: desarmar o passado para construir o futuro ...}

À medida que o tempo vai distanciando as recordações pessoais de determinados acontecimentos, a memória dá lugar à história (Lowenthal, 1995). Mas, ao mesmo tempo que o passado se parece afastar de nós, procuramos cada vez mais evocálo, ampliando a parafernália de meios de memória que o cercam (Lowenthal, 1995). Apesar das imagens dos acontecimentos passados perdurarem no nosso espírito, "não subsistem, numa galeria subterrânea dos nossos pensamentos, imagens completamente prontas, mas na sociedade, onde estão todas as indicações necessárias para reconstruir tais partes do nosso passado" (Halbwachs, 1990 [1950]: 77). É neste contexto que os lugares de memória se apresentam como meios por excelência, pois sem eles "as pessoas e as suas vidas passariam a ser imagens instantâneas, fantasmáticas" (Godinho, 2014a: 197)

O conceito de lugar de memória foi-nos introduzido por Pierre Nora e define lugares que são materiais, pelo seu conteúdo demográfico; simbólicos por definição, dado que são caracterizados por um acontecimento ou experiência vividos por um reduzido número de pessoas; e funcionais porque garantem a cristalização da lembrança e a sua respectiva transmissão. Assim, poder-se-ia dizer 


\section{perifèria}

Número 21(1), junio 2016

http://revistes.uab.cat/periferia

que a razão de ser de um lugar de memória é embalsamar o tempo, "bloquear o trabalho do esquecimento, fixar um estado de coisas, imortalizar a morte, materializar o imaterial para (...), prender o máximo de sentido num mínimo de sinais" (Nora, 1984: 22).

Como refere Oliveira a memória coletiva e a história aplicam-se tanto a monumentos, como a documentos, sendo que entende-se como monumento "manifestações escultóricas, arquitetónicas e, especialmente, objetos artísticos" (Oliveira, 2009: 13). Posto isto, é possível afirmar que as manifestações escultóricas carregam uma áurea simbólica forte e encontram-se imbuídas de historicidade, pelo que "a reflexão direcionada a partir das relações da memória e da história torna-se um importante subsídio, na tarefa de elucidar algumas questões relativas à interação entre arte e memória" (Oliveira, 2009: 7). As esculturas enquanto lugar de memória suscitam uma suspensão do presente e uma manipulação da história e da memória como referenciais identitários (Peralta, 2011).

Ainda, como propõe Nora, "nenhum lugar de memória escapa aos seus arabescos fundadores" (Nora, 1984: 22), pelo que qualquer lugar de memória torna-se naquilo que querem os seus fundadores, até porque se assim não o fosse perderia a sua virtude enquanto tal. Independentemente de tal instrumentalização, continuam a emergir ligados a si acontecimentos e datas-chaves que deambulam entre o passado e o presente "sem se fixarem em tempo algum" (Peralta, 2011: 229). Por este motivo as esculturas podem ser entendidas como espaços liminares, são "the betwixt and between" (Schechner, 1986: 7).

Assim, as esculturas, como iremos verificar no caso de Gonçalo Mabunda, dão lugar a uma "fronteira, a terra de ninguém, que foi zonal e se tornou linear" (Godinho, 2014в: 12). Esta é uma fronteira perigosa, sendo um "espaço marginal, periférico, descontrolado - porque fora de controlo pelos centros - torna-se zona de refúgio" (Godinho, 2014в: 12) e um lugar de resistência. É este uma soleira que se situa entre a memória e a história, entre as memórias fortes e as memórias fracas, "separa o que está fora do que já é interior. É uma passagem em que nos 


\section{perifèria}

Número 21(1), junio 2016

http://revistes.uab.cat/periferia

demoramos, num tempo-espaço criativo, entre duas margens" (Godinho, 2014в: 11).

Deste modo, dou o mote para apresentar o projecto do TAE (Transformação de Armas em Enxadas), iniciado pelo Conselho Cristão de Moçambique em colaboração com o Núcleo de Arte de Maputo. Este foi um projecto que, como já havia referido, consistia na colecta, troca e destruição de armas, para as transformar em peças de arte, visando "fortalecer a democracia e a sociedade civil encorajando a população a participar de forma ativa em atividades de manutenção da paz, promovendo a reconciliação e facilitando o início de atividades" (Faltas e Paes, 2004: 19). Posto isto, foram levadas a cabo diversas formações no Núcleo de Arte de Maputo que permitiram aos artistas adquirir as ferramentas necessárias para transformar as armas em arte. Como me confirmava Gonçalo Mabunda, um dos artistas do núcleo, "em 1997 propuseram aos artistas moçambicanos, 10 artistas, utilizarem as armas para criar obras de arte. Os artistas aceitaram o desafio e então foi realizado um workshop onde se criaram obras de arte com as armas" (Entrevista a Mabunda, 2015).

Deste modo, os artistas colocam a cultura em cena através destas esculturas fabricadas a partir de fragmentos bélicos, tendo como ponto de partida a memória social e traumática da Guerra Civil Moçambicana. Como se irá verificar através do trabalho de Gonçalo Mabunda, o artista, partindo das memórias fracas, leva a cabo uma «reciclagem» e reprodução dos ícones de guerra, de forma a criar toda uma produção identitária baseada na memória histórica. As esculturas apresentar-se-ão como um lugar de memória liminar que permite a negociação de significados e mnemónicas associadas à Guerra Civil, espelhando contra-memórias coadas pelas experiência pessoal do artista. Assim a tradição seria inventada, através da capacidade expressiva e simbólica da linguagem escultórico-performativa enquanto comunicadora de significados sociais ou políticos, e da mise-èn-scene do «drama social».

\section{Gonçalo Mabunda: "a historia não enterramos, mas reconstruimos"}




\section{perifèria}

Número 21(1), junio 2016

http://revistes.uab.cat/periferia

Armas. Fragmentos e fragmentos de armas. Armas que dão forma a um cadeirão. Um canhão de uma bazuca transforma-se num saxofone, a extremidade de um AK47 num corpo de mulher, cápsulas de balas formam o dorso de um crocodilo, e um mecanismo G3 compõe uma rosa. Sobraçando a máscara de solda em seu rosto, Gonçalo Mabunda debruça-se sobre os fragmentos de armamento, unindo os materiais bélicos através da máquina de soldar. As ideias, refere, "surgem do que acontece ao meu redor e daquilo que vou reflectindo..." (Entrevista a Mabunda, 2015).

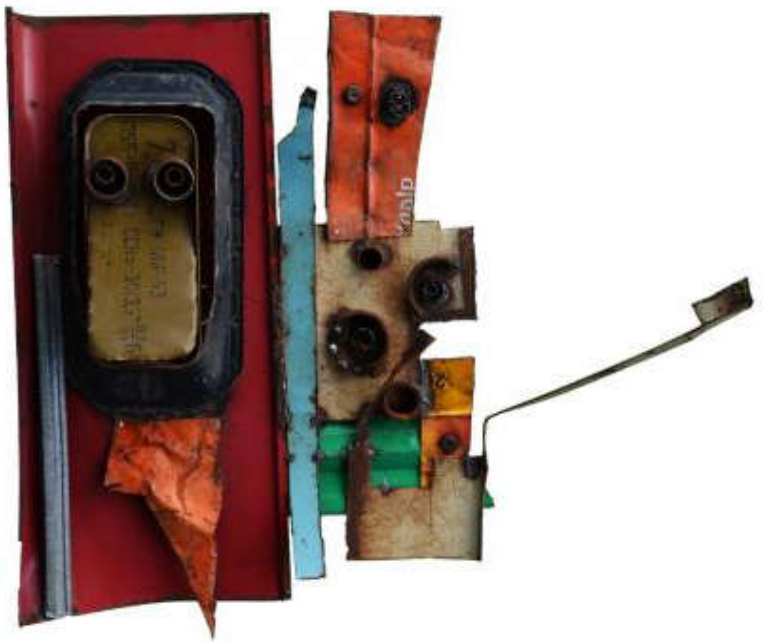

Fig. 2 - Sou jovem para ser desempregado e velho para trabalhar, escultura por Gonçalo Mabunda ${ }^{3}$.

Se a História é composta por memórias fortes, memórias de carácter hegemónico, as «memórias fracas», marcadas pela ucronia, acalentam-se na memória dos grupos subalternos, das minorias (Godinho, 2014a). Assim, num jogo entre as memórias fracas e fortes, Gonçalo Mabunda revolta-se contra as tentativas de hegemonização memorial impostas geralmente em países com longas ditaduras ou guerras civis, que se esforçam pela "recuperação da versão dos vencidos, obstando

3 Fonte: Gonçalo Mabunda. (2013) «Sou jovem para ser desempregado e velho para trabalhar». Disponível em < http://www.goncalo-mabunda.com/pt-pt/diversos> [consultado a 15 de Maio de 2016]. 


\section{perifèria}

Número 21(1), junio 2016

http://revistes.uab.cat/periferia

às memórias paraplégicas" (Godinho, 2014a: 195), não permitindo que um determinado segmento da sociedade aí se sinta reflectido (Godinho, 2014a). Procura, deste modo, reflectir as memórias fracas, referindo que "a historia não enterramos mas reconstruimos, dando outro sentido, um sentido de paz e de reflexão sobre a nossa historia" (Entrevista a Mabunda, 2015).

Gonçalo já trabalhava com metal antes, mas com as armas teve maior projecção a nível internacional. Refere: "'Comecei a trabalhar como estafeta, e nas horas vagas ia para o ateliê ver o que estava a acontecer. De vez em quando davam-me as sobras das tintas, e fazia os meus próprios quadros. Fui experimentando, experimentando..." (Anjos e Silva, 2013), até que foi bater à porta do Núcleo de Arte de Maputo. A sua primeira obra com armas, $O$ Viajante, foi construída em partes separadas, de forma a representar aqueles que foram mortos e esquecidos nos anos da guerra. Os seus familiares e vizinhos mortos durante a Guerra Civil ouviam agora a sua voz reflectida no metal (Raghavan, 2012). Era esta uma forma de mise-en-scène do drama social da Guerra Civil Moçambicana, "uma plataforma dramatúrgica, um palco, onde o drama social em questão é performatizado de acordo com um script particular" (Peralta, 2011: 221), evocando as memórias fracas e relação entre memória e performatividade.

Referia-nos Paul Connerton que a nossa experiência do presente depende do nosso conhecimento acerca do passado, estando a nossa percepção do mundo presente irremediavelmente submetida a acontecimentos e objectos do passado. Vivemos o nosso presente de acordo com os diferentes passados que com este se podem relacionar (Connerton, 1999). Assim, "as nossas imagens desse passado servem normalmente para legitimar a ordem social presente" (Connerton, 1999). Deste modo, a transmissão e conservação das imagens do passado e o conhecimento dele recolhido são permitidas através de performances como estas que Gonçalo Mabunda põe em cena. Assim, esta mise-en-scene do drama social rapidamente se transforma em «lugar de memória». De facto, Gonçalo Mabunda joga com a subversão e emblematização dos imaginários associados à Guerra Civil e aos objectos que a caracterizam, permitindo colocar em cena rearticulações do passado no presente. Esta instrumentalização da memória sobraçada por Gonçalo Mabunda pode ser integrada nas formas de resistência locais, que posteriormente se 


\section{perifèria}

Número 21(1), junio 2016

http://revistes.uab.cat/periferia

autonomizam e ampliam à escala global. Assim, decidi dar o salto para questões da resistência através da performance metaforizada.

\section{Esculpindo a resistência...}

A agência (...), constitui o substrato, as cinzas dormentes que poderão desatar em chamas sob a forma de um acto de resistência. (Mahmood, 2006: 127)

Referia Antonin Artaud que "a música age sobre as serpentes, não é pelas noções espirituais que ela Ihes traz, mas porque as serpentes são compridas, porque se enrolam longamente sobre a terra, porque seu corpo toca a terra em sua quase totalidade" (Artaud, 1983: 91). A metáfora de Artaud é sugestiva. A performance teria também essa capacidade de agir para com os espectadores, de os atingir como as vibrações musicais que se comunicam à terra. É neste ponto que a performance, neste caso a performance escultórica, pode ser a própria matéria de resistência, pois a performance, como salientava Turner, "inverts, perhaps lies to it self, and puts everything so to speak in the subjunctive mood as well as the reflexive voice" (Turner, 1986: 25).

Quando se fala em resistência há, geralmente, um nome que ressalta como contas de gravilha a ritmo apressado: o antropólogo e cientista político James C. Scott. O seu livro denominado Domination and the Arts of Resistance: Hidden Transcripts (2000 [1990]) tem vindo a adquirir uma enorme relevância no âmbito dos estudos sobre poder e resistência. O livro, que foi revisto e criticado por alguns autores com maior incidência sobre os argumentos que dizem respeito à natureza da hegemonia, à racionionalidade da acção política e à lógica de explicar revoluções, apresentou-se como um contributo importante para eu navegar pelas questões da resistência num âmbito mais geral, antes de mergulhar no campo artístico. Antes de explicitar o argumento do autor e o submeter a um, em alguns casos exagerado, apedrejamento teórico, gostaria de salientar que a meu ver a linha de força do livro é definitivamente o exímio facto deste se debruçar de forma 


\section{perifèria}

Número 21(1), junio 2016

http://revistes.uab.cat/periferia

absolutamente caleidoscópica sobre exemplos de performances de resistência e rituais subalternos.

Portanto, na obra cima referida, James C. Scott, focando-se essencialmente na linguagem e ideologia, procurou compreender as estratégias de resistência levadas a cabo pelo campesinato malaio. A conduta deste, tal como o autor havia verificado para o campesinato pobre de Sedaka, recorria ao disfarce, engano, e todo o tipo de comportamento evasivo, mantendo em situações de poder a máscara da aceitação. Assim, o autor rapidamente se apercebeu que, dado o poder dos grupos dominantes, a luta subalterna era necessariamente prudente. Em vez de se rebelarem ou protestarem directamente, recorriam a outras formas de resistência, optando por evitar qualquer confronto directo com os grupos dominantes (Scott, 2000).

Não há dúvida de que o poder impõe à força as aparências que os grupos subalternos devem adoptar, mas isso não impede que estes as usem enquanto um instrumento de resistência e evasão. O teatro do poder pode converter-se num verdadeiro instrumento político dos subordinados. Assim, a maior recomendação de Scott para compreender a resistência dos grupos subordinados é examinar como as relações de poder afectam o que as pessoas dizem perante diferentes audiências sociais (Scott, 2000). E é precisamente neste ponto que, de acordo com Susan Gal, o argumento se apresenta problemático (Gal, 1995). Desde já se salienta que as principais categorias analíticas utilizadas pelo autor - dominantes e subalternossão tão generalizadas no espaço e no tempo que importantes diferenças culturais entre formas de poder não podem ser percepcionadas através desta proposta (Gal, 1995).

Mas retomando os argumentos James Scott, este concentrando-se no significado político do discurso, essencialmente constituído por actos performativos, desenvolve aquilo a que se pode chamar de uma dramaturgia do poder. Distinguenos, numa tradução meio tosca, entre «discurso público» e «discurso oculto» (Scott, 2000). O discurso público seria o autorretrato das elites dominantes, sendo que, tendo em conta a sua capacidade de impor aos outros um modelo de comportamento, este está em desequilíbrio. É um discurso que está feito para 


\section{perifèria}

Número 21(1), junio 2016

http://revistes.uab.cat/periferia

"impresionar, para afirrnar y naturalizar el poder de las élites dominantes, y para esconder o eufemizar la ropa sucia del ejercicio de su poder" (Scott, 2000: 42).

Scott apresenta o discurso público como uma forma de acção, actuação e encenação, bebendo ligeiramente da concepção Goffmaniana que procura as manifestações performativas da vida quotidiana no campo da fachada (Goffman, 2011). Mas, enquanto a metáfora dramatúrgica de Goffman sugere que todos os indivíduos na ordem da interacção são actores e que a "fachada torna-se uma "representação coletiva" e um fato, por direito próprio" (Goffman, 2011: 34), Scott apresenta a actuação como uma imposição que força maioritariamente os subalternos (Scott, 2000).

Quanto ao «discurso oculto», este apresenta-se como evasivo e muitas vezes inacessível. De acordo com Scott, "en éste, fuera del escenario, donde los subordinados se reúnen lejos de la mirada intimidante del poder, es posible el surgimiento de una cultura política claramente dissidente" (Scott, 2000: 43). Um dos problemas que Gal levanta em relação à definição de discurso oculto de Scott é que esta "ignores the fact (...), that any transcript is itself a socially constructed artifact, created for definable purposes that depend the goals of the transcriber, and can be neither complete nor the objective view from nowhere that Scott definition suggests (Gal, 1995: 414).

Estes géneros de resistência ideológica formam aquilo a que James C. Scott chamou de «infrapolítica dos grupos subalternos», sendo "the indispensable and revealing percursor of those elaborate insitutional political actions, such as revolutions and the formation of social movements" (Gal, 1995: 408). Algumas da críticas que Susan Gal (1995) faz a esta dramaturgia do poder é o facto de Scott ignorar "the possibility that gramatical categories could contribut to tacit hegemony" (Gal, 1995:409); Outra crítica levantada faz referência à ideia de que algumas estratégias paradigmáticas como a ambiguidade ou ironia são assumidas por Scott como tendo funções intrínsecas de subversão e resistência, independentemente das ideologias linguísticas e contextos culturais onde estas estão acantonadas (Gal, 1995). 


\section{perifèria}

Número 21(1), junio 2016

http://revistes.uab.cat/periferia

O grande problema da proposta de Scott tem a ver com a ferramenta conceptual, com a distinção entre público e oculto. O que distingue, de facto, o discurso público do oculto? Ou de que perspectiva devemos olhar para o discurso oculto? Retirando um exemplo a James Scott, o autor refere que o movimento negro pelos direitos civis recorreu a um discurso oculto entre os estudantes negros, clérigos, etc., mas, no entanto, muitas dessas estratégias subalternas entre as elites negras foram reportadas no jornais (Scott, 2000). De que forma esse discurso pode ser oculto? Considero que, de facto, entre as várias críticas, a mais relevante se prende ainda com a formulação de Scott dessa tal ideia de público. Isto, porque a ideia de público está longe de ser apenas uma questão de ter audiência, baseada numa ideia de interacção face-a-face. É ela mesma uma construção ideológica do pensamento ocidental. Como referia Gal, baseando-nos na história Europeia podemos ver a noção de público como uma lógica de legitimação do poder político, assim a proposta de Gal é desenvolver-se uma forma de oposição a este mecanismo ideológico, como por exemplo, "the creation of alternate publics" (Gal, 1995: 418).

Mas não me querendo focar em críticas que, pela relevância da obra, ficaram perdidas na noite dos tempos, saliento que, a par deste contributo de James $C$. Scott para os estudos da resistência e poder, vir-me-ia a ser mais útil, e adequada ao meu objecto de estudo, a teorização de Lila Abu-lughod em "The Romance of Resistance: Tracing Transformations of Power Through Bedouin Women" (1990). Refiro-o, em parte, porque o meu interesse não são estes grandes estudos acerca da resistência e insurgência do campesinato, mas sim essa nova abordagem às formas de resistência singulares, pois "deve-se aos agentes sociais, que agem e atuam, usando, dilatando e recompondo as suas capacidades, o tecido do social feito com o fio do tempo" (Godinho, 2014: 11). Ou seja, como referia Abu-Lughod, "hablamos de subversiones - más que de insurrecciones colectivas a gran escala-, de resistencias pequeñas o locales no vinculadas al derrocamiento de los sistemas de poder, ni siquiera a las ideologías de emancipación" (Abu-lughod, 1990: 180), como se apresentará para o caso da escultura.

A proposta da Lila Abu-lughod apresenta-se bastante frutífera, dado que sugere utilizar a resistência como um diagnóstico de poder. Como refere a autora, muitas 


\section{perifèria}

Número 21(1), junio 2016

http://revistes.uab.cat/periferia

das abordagens ao tema da resistência como de Bourdieu ou Gramsci "están más interesados en buscar resistentes y en explicar la resistencia que en analizar el poder, me parece que no exploran tanto como podrían las implicaciones de las formas de resistencia que localizan" (Abu-lughod, 1990: 181).

Abu-lughod destaca ainda que nos seus primeiros estudos, bem como de outros teóricos velhos do Restelo, era visível a tendência para transmitir uma visão romântica da resistência, "a interpretar todas las formas de resistencia como signos de la ineficacia de los sistemas de poder y de la capacidad y creatividad del espíritu humano en su negativa a ser dominado" (Abu-lughod, 1990: 182). Isto fazia com que deixassem de diferenciar as diversas formas de resistência, dando por fechadas algumas questões acerca dos mecanismos de poder (Abu-lughod, 1990).

Ao sugerir usar a resistência como diagnóstico de poder, a autora retorna aos argumentos de Foucault, que, visando um questionamento acerca do poder como algo eterno e maioritariamente repressivo, afirmava que "donde hay poder, hay resistencia" (Abu-lughod, 1990: 182). A ideia era demonstrar que o poder não funciona apenas negativamente, negando, restringindo e proibindo, mas também positivamente, produzindo sistemas de conhecimento, discursos, formas de prazer, salientando ainda que "esta resistencia nunca está en posición de exterioridad con respecto al poder" (Abu-lughod, 1990: 182).

De modo a que possamos compreender melhor esta visão da resistência e também de uma forma menos problemática, por permitir transcender as teorias abstractas do poder, a autora procurou revertê-la, afirmando que «donde hay resistencia, hay poder»(Abu-lughod, 1990: 183). Assim, evidencia uma estratégia metodológica que nos permite estudar o poder em situações concretas, "en los ricos y a veces contradictorios detalles de la resistencia"(Abu-lughod, 1990: 183), permitindo-nos analisar a transformação processual das relações de poder. Através das formas de resistência é possível entender melhor as estruturas tradicionais do poder, como se irá verificar no caso das obras de Gonçalo Mabunda.

De acordo com Gonçalo Mabunda, "com as armas tento passar a mensagem oposta de que a arma foi feita para matar, ou seja, na minha obra as armas tem um motivo de lazer (estético) e de reflexão" (Entrevista a Mabunda, 2015). Assim o é 


\section{perifèria}

Número 21(1), junio 2016

http://revistes.uab.cat/periferia

na sua obra mais célebre, o «trono africano». Esta é uma escultura em forma de cadeirão, feita a partir de armas do tipo AKM-47, que remete para o facto da história do continente africano se ter consolidado a partir de lutas armadas. Para Gonçalo as AKM-47 são o objecto que para si adquire um maior significado e simbolismo, porque, segundo o artista, "é das armas mais baratas e que mais mata a nível mundial" (Entrevista a Mabunda, 2015), pelo que para si "quanto mais destas armas destruir mais me sinto realizado" (Entrevista a Mabunda, 2015).

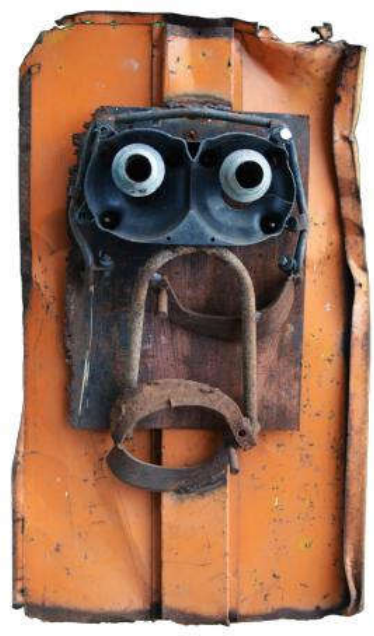

Fig. 3 - Patrão Estrangeiro, escultura por Gonçalo Mabunda ${ }^{4}$.

Gonçalo forja a ferro e fogo peças artísticas que gritam a memória de uma guerra civil arrastada, visando sensibilizar o público para a situação politica e social africana, mas também mundial. O artista reúne na sua exposição Ilegível Memória (2013), uma série de obras construídas a partir de metais e armas desactivadas com nomes bastante sugestivos: «Dá ao povo o que é de César», «sou jovem para ser desempregado e velho para trabalhar», ou «patrão estrangeiro» intitulam esculturas que fazem parte desta exposição. Entre estas está a escultura «O viajante inocente», referência explicita à declaração de paz, figurando um homem

\footnotetext{
4 Fonte: Gonçalo Mabunda. (2013) «Patrão Estrangeiro». Disponível em <http://www.goncalo-
} mabunda.com/pt-pt/patrao-estrangeiro> [consultado a 14 de Maio de 2015]. 


\section{perifèria}

Número 21(1), junio 2016

http://revistes.uab.cat/periferia

numa mota que, após a assinatura da declaração da paz no seu país, decide viajar de Maputo a Rovuma e do Zumbo ao Índico.

De acordo com o testemunho do artista "visa a minha obra furar barreiras que através da linguagem "normal" não se furam. As obras de arte acho que conseguem ter mais voz" (Entrevista a Mabunda, 2015). Assim, o artista acredita que passa uma mensagem à sociedade, não necessariamente política, embora refira que "quando se fala de armas é mais politico" (Entrevista a Mabunda, 2015). Acrescenta, "não acredito nos políticos" (Entrevista a Mabunda, 2015).

É possível compreender as esculturas de Gonçalo como fontes explicitadoras/denunciadoras, ou até mesmo, criadoras de tensões. Através da transformação das armas em artes, o artista procura fomentar dissensos, tornando visível o que os consensos dominantes tentam obscurecer ou apagar. As obras de Mabunda são intervenções contra-hegemónicas cujo objectivo se pauta por pertubar a imagem que o consenso hegemónico tenta forjar. $E$, de facto, a escultura, como a peste, tem essa vantagem de "afetar todos os lugares do corpo, todas as localizações do espaço físico, em que a vontade humana, a consciência e o pensamento estão prestes e em via de se manifestar" (Artaud, 1983: 17). Deste modo, a escultura reencontra a noção das figuras e símbolos-tipos que "agem como se fossem pausas, sinais de suspensão, paragens cardíacas, acessos de humor, acessos inflamatórios de imagens em nossas cabeças bruscamente despertadas" (Artaud, 1983: 24), que evocando contra-memórias, discursos subversivos e dissidentes, funcionam como arma dos fracos (Scott, 1990).

As esculturas de Mabunda acentuam a relevância da posse de armas como fonte de poder, ao mesmo tempo que materializam os discursos dissonantes e subversivos da sociedade moçambicana. Através destas esculturas fabricadas com fragmentos de armamento o artista expressa ideias radicalmente opostas àquelas que o objecto isolado transmite funcionalmente. Isto permite uma valorização da resistência, associada a uma esfera pública, na qual o objecto artístico sob à cena. É este um valor que se apresenta contraditório com os próprios objectos em que se estrutura a arte. $O$ artista aproveita esta contradição para resistir e reafirmar não apenas o estatuto do objecto artístico e simbólico, mas também as próprias memórias que 


\section{perifèria}

Número 21(1), junio 2016

http://revistes.uab.cat/periferia

ele evoca. A questão que coloco em relação ao impacto destas esculturas na sociedade moçambicana é semelhante à que Lila Abu-lughod colocou no caso da poesia beduína, ou seja, será que a ideologia oficial é sempre hegemónica? Será que a resistência cultural conta tanto quanto resistência de outra índole?

O objectivo inicial do projecto de transformar as armas em arte não era que este fosse uma iniciativa comercial. No entanto, rapidamente a publicidade e marketing relativo às esculturas transformou os objectos artísticos em apetecíveis mercadorias, fazendo com que certos artistas do Núcleo de Arte de Maputo transitassem para outros projectos, estando esta iniciativa agora ser apropriada de outras formas por grupos distintos, tendo em vista objectivos económicos. O que considero importante referir aqui é que apesar da mediatização que o projecto encontrou em Moçambique, este acabou por se projectar mais para o exterior, acabando por não adquirir grande expressão no seu próprio país.

Faltas e Paes (2004) descrevem, no seu estudo sobre o projecto TAE, o acompanhamento de uma visita da equipa do TAE à cidade de Mopeia, visando a destruição e recolha de armas para o projecto. Referem ter sido realizada uma cerimónia que incluiu discursos dos dignatários locais, todavia jamais foi feita referência à transformação das armas em arte, sendo que a justificação dada pela equipa foi que "as pessoas não entenderiam as ideias dos artistas e que mostrar as peças poderia ter até mesmo um impacto negativo, já que a população supersticiosa do vilarejo poderia confundi-las com magia" (Faltas e Paes, 2004: 35). O que se poderia apreender disto à primeira vista é que, no caso de Moçambique, as formas artísticas da resistência estão a perder importância no campo das relações de poder, principalmente fora das zonas urbanas e nas camadas mais jovens. Poderia nomear como argumento justificativo para isto outros meios de comunicação, como a rádio ou o espaço cibernético que se assumem como espaços de comunicação por excelência, bastante propícios à proliferação de ideias dissonantes. Mas, por outro lado, visivelmente o acesso por determinados segmentos populacionais a este modo de resistência é absolutamente boicotado pelos próprios Conselho Cristão de Moçambique e Núcleo de Arte de Maputo, revelando a ambiguidade das relações de poder. 


\section{perifèria}

Número 21(1), junio 2016

http://revistes.uab.cat/periferia

O interesse internacional pelas esculturas resultou a que tenham sido levadas num tour pelos Estados Unidos, Grã-Bretanha, Itália e França (Faltas e Paes, 2004: 32), dando uma nova vida à visibilidade deste tipo de arte. Porém, isto levou a que o TAE interrompesse o fornecimento de armas aos artistas por, ao exporem as obras por sua conta, deixaram de beneficiar financeiramente o projecto (Faltas e Paes, 2004). Deste modo, é possível perceber que as esculturas são pensadas e produzidas dentro de relações de poder, e evocam e produzem representações acerca dessas mesmas relações de poder, pelo que, como referia Lila Abu-Lughod parafraseando Foucault, "no entendemos la resistencia como una fuerza de reacción en parte independiente o fuera del sistema de poder (Abu-lughod, 1990: 193). Isto permite-nos compreender que em relação a estas formas de resistência singulares, na linha de pensamento da Lila Abu-Lughod (1990), certas relações de poder operam através da restrição dos movimentos e actividades diárias dos subalternos, o que se justifica, por um lado, porque motivo o projecto da TAE tem tão pouca visibilidade em Moçambique e noutros contextos africanos, enquanto ganhou uma mediatização enorme fora do continente africano; por outro, porque motivo foi boicotado a certos segmentos da população o acesso às esculturas, bem como o acesso às armas por parte dos artistas. É certo que, em termos ideológicos, a mensagem que os artistas procuravam transmitir através das esculturas se mantém fundamentalmente a mesma, embora um pouco mais abrangente, porque, como me referia Gonçalo Mabunda, "a guerra existe não apenas em Africa" (Entrevista a Mabunda, 2015). 


\section{perifèria}

Número 21(1), junio 2016

http://revistes.uab.cat/periferia

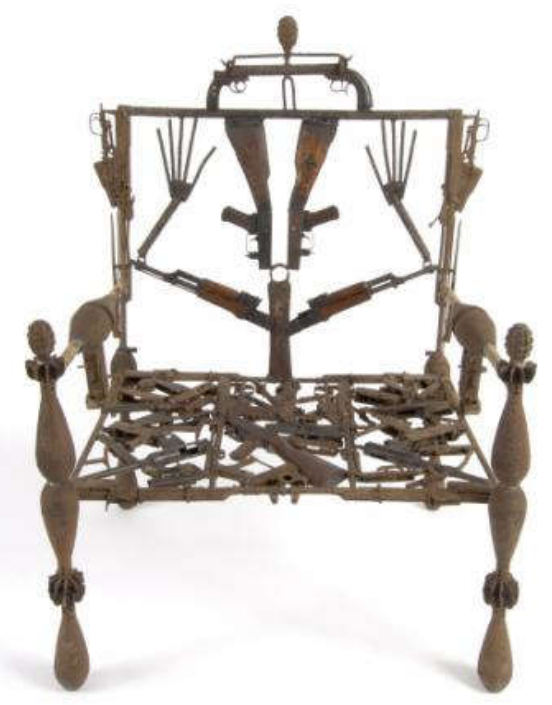

Fig. 4 - Trono de um rei africano, escultura por Gonçalo Mabunda 5 .

\section{Considerações finais}

Podemos concluir que este tipo de resistência não é de modo algum independente dos sistemas de poder, sendo que o interesse está em perceber a peculiaridade destas formas de resistência, ou seja, compreender "cómo viajan entre dos sistemas y qué pueden decirnos de las relaciones de poder en tales condiciones" (Abu-Lughod, 1990: 199). Os discursos e manifestações de resistência que as esculturas do Gonçalo Mabunda evocam não são discursos embebidos apenas no seu contexto de origem, ou seja a sociedade moçambicana, mas reflectem a influência internacional, bem como a omnipresença do Estado. Isto faz com as esculturas e os artistas se vejam envoltos em relações de poder imensamente complexas que unem a economia africana e submetem a percepção artística local aos ímpetos e contextos mundiais, fazendo com que estas formas de resistência, inicialmente locais, sejam englobadas num fluxo global e adaptadas a diferentes

\footnotetext{
5 Fonte: Gonçalo Mabunda. (2004) «Trono de um rei africano ». Disponível em <http://www.goncalomabunda.com/pt-pt/tronos> [consultado a 14 de Maio de 2015].
} 


\section{perifèria}

Número 21(1), junio 2016

http://revistes.uab.cat/periferia

sistemas de poder que variam de acordo com as diferentes sociedades. Assim, como refere Abu-Lughod, "esto puede hacer pensar en cajas dentro de cajas dentro de cajas. Pero es una imagen errónea. Más adecuada sería la imagen de campos que se solapan y formas de sometimiento que se entrecruzan y cuyos efectos en individuos ubicados en momentos históricos específicos varían tremendamente" (Abu-Lughod, 1990: 204).

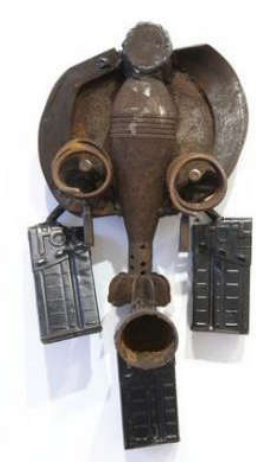

Fig. 5 - Máscara africana, escultura por Gonçalo Mabunda6.

Um bom exemplo do cruzamento destes campos é a escultura das máscaras africanas de Gonçalo Mabunda, pois denunciam "a utilização de elementos antigos na elaboração de novas tradições inventadas para fins bastante originais" (Hobsbawn, 1984: 14). Se de um ponto de vista local podem ter sido inspiradas nas máscaras tribais e simbolizar as transformações sociais e políticas pelas quais Moçambique passou, evocando as várias máscaras que o país sobraçou ao longo do seu «drama social», desde a independência em 1975, ao modelo comunista e à frágil democracia; Máscaras colocadas umas após outras, umas dando face ao nacionalismo, outras ao socialismo, à modernidade, à liberdade de expressão; Por outro, simbolizam, de um ponto de vista mais geral e globalizante, a "nova falsidade que existe, porque existem muitas pessoas hoje em dia com duas caras" (Entrevista a Mabunda, 2015). Se, por um lado, o artista é "influenciado pela

\footnotetext{
6 Fonte: Gonçalo Mabunda. (2011) «Mask». Disponível em <http://www.goncalo-mabunda.com/ptpt/mascaras $>$ [consultado a 14 de Maio de 2015].
} 


\section{perifèria}

Número 21(1), junio 2016

http://revistes.uab.cat/periferia

tradição africana" (Entrevista a Mabunda, 2015), por outro, bebe de referências como Braque e Picasso e procura "sensibilizar não apenas para a situação africana mas mundial" (Entrevista a Mabunda, 2015).

É possível também aferir que uma análise desta possível reinvenção/ adaptação das obras ao contexto internacional, bem como transformação de objectos de guerra em objectos artísticos não se pode esgotar na tão célebre dicotomia «tradição/costume» evidenciada por Hobsbawn, que faz a distinção entre "tradição", inventada e manipulada com vista a um fim, e "costume", próprio das sociedades ditas tradicionais (Hobsbawn, 1984). Dar demasiada importância a esta febre dicotómica seria incorrer numa outra dicotomia que classifica as coisas numa dualidade verdadeiro/falso, partindo do pressuposto que apenas as esculturas baseadas na antiga tradição e produzidas no contexto tradicional são genuínas e autênticas. Ainda que a proposta de estudo destas tradições ou reinvenções se apresente frutífera como uma forma de esclarecer as relações humanas com o passado (Hobsbawn, 1984), como vimos no caso das esculturas de Mabunda que têm uma estreita relação com memorias traumáticas da Guerra Civil Moçambicana, ela tende a evocar uma recorrente instrumentalização do passado, e, como nos demonstra Peralta, o passado, conforme representado no "presente", não pode ser um produto exclusivo de uma manipulação politico-ideológica. Este corresponde não só à forma como um determinado colectivo se auto-representa, mas também à forma como é representado, pois a memória social é "um espaço de contestação entre diferentes vozes, cada uma delas procurando fazer ouvir a sua versão do passado" (Peralta, 2007: 14). Em suma, o passado integra as vidas de cada um independentemente de uma instrumentalização que possa existir dessa memória, deste modo, a memória social constitui-se através da integração de diferentes passados individuais num passado comum a um colectivo de individuos, sendo que as manifestações escultóricas de Gonçalo Mabunda, ao transportarem tanto memorias hegemónicas reivindicadas à história oficial, como memorias fracas e traumáticas, são uma manifestação por excelencia desta multiplicidade.

\section{Bibliografía}




\section{perifèria}

Número 21(1), junio 2016

http://revistes.uab.cat/periferia

Abu-lughod, Lila (1990). "La resistencia idealizada: trazando las transformaciones del poder a través de las mujeres beduínas", Em American Ethnologist, vol. 17, n.o 1 (Feb.), pp. 41-55 [Trad. María Enguix].

Burgess; R., (1997). "As entrevistas como conversas" in A Pesquisa de Terreno, Lisboa: Celta pp., 111-133.

Connerton, Paul (1999). Como as sociedades recordam. Oeiras, Celta Editora, pp. 1-7; 47- 119 .

Couto, Mia (1996). A Varanda do Frangipani, Lisboa: Editorial Caminho.

Cruz e Silva, Teresa (2001). "Moçambique: um perfil", Projecto Reivenção da Emancipação Social, Centro de Estudos Sociais - Laboratório Associado Universidade de Coimbra. Disponível em <http://www.ces.uc.pt/emancipa/gen/mozambique.html> [consultado a 20 de Maio de 2016].

Dawsey, John C. (2007). "Sismologia da performance: Ritual, drama e play na teoria antropológica", Em Revista de antropologia, São Paulo, USP, V. 50 No 2.

Faltas, Sami e PAES, Wolf-Christian (2004). "Transformação de armas em enxadas: a abordagem TAE para um desarmamento práctico", Em Bonn internatinal center for conversion, Alemanha: BICC. Disponível em <https://www.bicc.de/uploads/tx_bicctools/brief29-port.pdf> [Consultado a 22 de Maio de 2015].

Gal, Susan (1995). "Language and the Arts of Resistance, Review of Domination and the Arts of Resistance: Hidden Transcripts by James Scott", Em Cultural Anthropology, Vol. 10, No. 3 (Aug. 1995) pp. 407-424. Disponível em <http://www.jstor.org/stable/656344?\&seq=1\#page_scan_tab_contents> [Consultado a 23 de Maio de 2015].

Godinho, Paula (2012). "Usos da Memória e práticas do património. Alguns trilhos e muitas perplexidades", Em Paula Godinho, coord. Usos da memória e práticas do património. Lisboa: Colibri. 


\section{perifèria}

Número 21(1), junio 2016

http://revistes.uab.cat/periferia

Godinho, Paula (2014a). "A violência do olvido e os usos políticos do passado: lugares de memória, tempo liminar e drama social", in Paula Godinho, coord. Antropologia e Performance - Agir, Atuar, Exibir. Castro Verde: 100Luz, pp. 193213.

Godinho, Paula (2014B). "Agir, atuar, exibir. Antropologia e Performance, uma introdução", in Paula Godinho, coord. Antropologia e Performance - Agir, Atuar, Exibir. Castro Verde: 100Luz, pp. 9-24.

Goffman, Erving (2011). A Representação do Eu na Vida Cotidiana. 14a ed., Editora Vozes, Petrópolis, pp. 1-40.

Halbwachs, M. (1990). A memória coletiva. São Paulo: Vértice / Editora Revista dos Tribunais. (Biblioteca Vértice de sociologia e política), pp.53-78.

Hobsbawn, Eric (1984). "Introdução: A Invenção das Tradições", Em HOBSBAWN, E. e RANGER, T. (org.), Em A Invenção das Tradições. Rio de Janeiro: Paz e Terra.

Leão, Ana (2004). Monograph 94 Portuguese: Armas em Mocambique, Em Programa de Gestão de Armas do ISS, Pretoria: Institute for Security Studies Publications, pp. 1-12; 20-29. Disponível em <https://www.academia.edu/11895326/Armas_em_Mocambique> [Consultado a 17 de Maio de 2015].

Lowenthal, David (1995). "Como conhecemos o passado", Em The past is a foreign country. 7a Edição. [Trad. Lúcia Haddad], Cambridge: Cambrigde University Press, pp. $63-180$.

Mabunda, Gonçalo. Entrevista por telefone. Lisboa/Paris: 12 de Maio de 2015. Entrevista concedida a Sílvia Gomes.

Malinowski, B. (1997). "Introdução: objecto, método e alcance desta investigação" em Os Argonautas do Pacífico Ocidental. Ethnologia, n.s., n6-8, pp.17-37. Disponível em: <http://www.moodle.ufba.br/file.php/12439/textos_complementares/Bronislaw_Ma linowski_Os_a rgonautas_do_Pacifico_Ocidental.pdf> [Consultado a 01 de Janeiro 


\section{perifèria}

Número 21(1), junio 2016

http://revistes.uab.cat/periferia

de 2016].

Mahmood, Saba (2006). "Teoria feminista, agência e sujeito liberatório: algumas reflexões sobre o revivalismo islâmico no Egipto", Em Etnográfica, X, Nº1.

Nora, Pierre (1984). "Entre memória e história - a problemática dos lugares", Em Les lieux de mémoire. I La République, Paris, Gallimard, pp. 18-42. [Tradução de Yara Aun Khoury].

Oliveira, A. M. (2009). "Arte como Lugar da Memória", Em Travessias (UNIOESTE. Online), v. 1, p. 1-26. Disponível em <https://pt.scribd.com/doc/208030756/ARTECOMO-LUGAR-de-MEMORIA-Alecsandra-Matias-de-Oliveira> [Consultado a 15 de Maio de 2015 ].

Peralta, Elsa (2007). "Abordagens teóricas ao estudo da memória social: uma resenha crítica", Em Arquivos da Memória (Antropologia, Escala e Memória), N.o 2 (Nova Série), CEEP.

Peralta, Elsa (2014). "O monumento aos Combatentes: a performance do Fim do Império no Espaço Sagrado da Nação", Em Paula Godinho, coord. Antropologia e Performance - Agir, Atuar, Exibir. Castro Verde: 100Luz, pp. 203-234.

Raghavan, Sudarsan (2012). «In Mozambique, transforming guns into art», em Washington Post, 08 de Novembro. Disponível em <http://www.washingtonpost.com/world/africa/in-mozambique-transforming-gunsinto-art/2012/11/07/a1231d44-2508-11e2-92f8-7f9c4daf276a_story.html> [consultado a 14 de Maio de 2015].

Ribeiro, V. R. (2014). Democracia e Conflito: A Sociedade Civil em Moçambique. Trabalho realizado no ámbito do curso de Ciência Política e Relações Internacionais - Instituto Universitário de Pesquisas do Rio de Janeiro, Universidade Cândido Mendes, Brasil. Disponível em < https://www.academia.edu/6363778/Democracia_e_Conflito__A_Sociedade_Civil_em_Mo\%C3\%A7ambique > [Consultado a 19 de Maio de 2015]. 


\section{perifèria}

Número 21(1), junio 2016

http://revistes.uab.cat/periferia

Rolletta, Paola (2008). Fiel dos Santos Sculpteur, Éditions de I'Oeil.

Schechner, Richard (1986). "Victor Turner's Last Adventure", Em TURNER, Victor (1986), The Anthropology of Performance, NY: PAJ Publications.

Scott, James (2000). Los Dominados y El Arte de la Resistencia, Ediciones ERA, S.A. de C.V., pp.17-71.

Spradley, J. (1979). The ethnographic interview. New York, NY: Holt.

Turner, Victor (1986). "Images and Reflections: Ritual, Drama, Carnival, Film, and Spectacle in Cultural Performance", Em The Anthropology of Performance, NY, PAJ Publications.

Turner, Victor (2008). "Dramas sociais e metáforas rituais", Em Drama, campos e metáforas, Niterói: EdUFF. Disponível em <http://www.do.ufgd.edu.br/mariojunior/arquivos/dramas_campos_metaforas.pdf $>$ [Consultado a 19 de Maio de 2015]. 